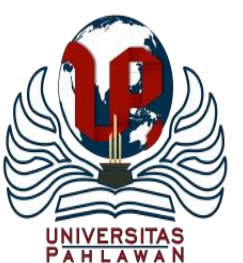

Jurnal Basicedu Volume 5 Nomor 1 Tahun 2021 Halaman 121-132

JURNAL BASICEDU

Research \& Learning in Elementary Education

https://jbasic.org/index.php/basicedu

\title{
Pembelajaran Matematika Realistik dalam Meningkatkan Hasil Belajar Matematika Materi Operasi Bilangan Pecahan
}

\author{
Hilaria Melania Mbagho ${ }^{1}$, Stefanus Notan Tupen ${ }^{2}$ \\ Program Studi Pendidikan Matematika, Universitas Flores, Jln. Sam Ratulangi, Ende ${ }^{1,2}$ \\ Email: hilariambagho130178@gmail.com ${ }^{1}$, stefnotan@gmail.com ${ }^{2}$
}

\begin{abstract}
Abstrak
Penelitian ini dilaksanakan di SMP PGRI 3 Paga dengan alasan rendahnya hasil belajar dalam proses pembelajaran Matematika. Pembelajaran Matematika bersifat transmitif artinya pengajaran menerapkan konsep-konsep secara langsung kepada siswa dan metode pembelajaran kurang bervariatif yaitu masih menggunakan pembelajaran konvensional yang menyebabkan siswa cepat bosan dengan pembelajaran Matematika. Hal ini dapat menyebabkan rendahnya hasil belajar siswa. Agar pembelajaran Matematika menjadi pembelajaran yang aktif, kreatif dan menyenangkan, maka dapat dilakukan melalui cara penerapan model Pembelajaran Matematika Realistik yang lebih menekankan pada adanya aktivitas siswa dan interaksi antar siswa untuk saling memotivasi dan saling membantu dalam menguasai materi. Rancangan penelitian ini adalah penelitian tindakan kelas yang dilaksanakan dalam dua siklus. Setiap siklus terdiri dari perencanaan, pelaksanaan, observasi, dan refleksi. Subjek penelitian ini adalah siswa kelas VII A SMP PGRI 3 Paga. Teknik pengumpulan data menggunakan metode observasi, wawancara, angket, pemberian tes hasil belajar, dan diskusi dengan guru mata pelajaran, dengan menggunakan analisis data kualitatif. Hasil penelitian menunjukan bahwa (1) penerapan Pembelajaran Matematika Realistik siklus I meningkat menjadi 65,55\% (kategori cukup), (2) pada siklus II meningkat menjadi 75,28\% (kategori baik). Kesimpulan dari penelitian ini adalah model Pembelajaran Matematika Realistik dapat meningkatkan hasil belajar siswa kelas VII SMP PGRI 3 Paga pada materi operasi bilangan pecahan.
\end{abstract}

Kata kunci: pembelajaran matematika realistik, operasi bilangan pecahan, hasil belajar

\begin{abstract}
This research was conducted in SMP PGRI 3 Paga with the reason of the low learning outcomes in the process of learning mathematics. Mathematics learning is transmitif means teaching applying concepts directly to students and the use of less-varied learning methods that is still using conventional learning with lecture methods that cause students quickly bored with mathematics learning. This can lead to low student learning outcomes. In order for mathematics learning to be active, creative and fun learning, it can be done through the application of realistic mathematics learning model that emphasizes on student activity and interaction among students to motivate and help each other in mastering the material. The design of this study is a classroom action research conducted in two cycles. Each cycle consists of planning, execution, observation, and reflection. The subjects of this study were students of Class VII A SMP PGRI 3 Paga. Data collection techniques used observation methods, interviews, questionnaires, test results, and discussions with subject teachers, using qualitative data analysis. The result of research shows that (1) the application of realistic mathematics learning cycle I increases to 65,55\% (enough category) (2) in cycle II increase to 75,28\% (good category). The conclusion of this research is realistic mathematics learning model can improve student learning result class VII SMP PGRI 3 Paga on the matter of fractional operation.
\end{abstract}

Keywords: realistic mathematics learning, fractional numbers, learning outcomes.

Copyright (c) 2021 Hilaria Melania Mbagho, Stefanus Notan Tupen

$\triangle$ Corresponding author

Address : Universitas Flores

Email : hilariambagho130178@gmail.com

ISSN 2580-3735 (Media Cetak)

Phone : Nomor HP Penulis

ISSN 2580-1147 (Media Online)

DOI : $\quad$ https://doi.org/10.31004/basicedu.v5i1.632 


\section{PENDAHULUAN}

Rendahnya hasil belajar siswa di SMP PGRI 3 Paga dalam pembelajaran Matematika bukan semata-mata karena materi yang sulit, tetapi juga bisa disebabkan oleh proses pembelajaran yang dilaksanakan. Pembelajaran dan pengajaran Matematika yang ditemukan masih berpusat pada guru. Sementara itu proses pembelajarannya dipraktikkan secara konvensional. Proses pembelajaran kelas tidak memberikan kesempatan kepada siswa untuk membangun pemahamannya sendiri sehingga siswa menjadi pembelajar pasif dan tidak berpartisipasi dalam proses pembelajaran. Siswa tidak dapat memahami pentingnya mempelajari algoritme dan hanya menghafal rumus tanpa memahami mekanikanya meskipun mengetahui bahwa mereka harus memahami konsep dan penggunaannya terlebih dahulu sebelum menghafalnya. Siswa diinstruksikan untuk menghafal banyak fakta dan harus mampu memuntahkannya selama ujian. Pentingnya proses pembelajaran ini ditegaskan oleh Soedjadi (1999) yang menyatakan bahwa: "Betapapun tepat dan baiknya bahan ajar Matematika yang ditetapkan belumlah menjamin akan tercapainya tujuan pendidikan Matematika yang diinginkan. Salah satu faktor penting untuk mencapai tujuan pendidikan adalah proses belajar yang dilaksanakan.”

Proses pembelajaran yang baik tentu akan berdampak positif terhadap hasil belajar siswa. Menurut Nana Sudjana (2010:22), hasil belajar adalah kemampuan yang dimiliki siswa setelah menerima pengalaman belajar. Selanjutnya Hasil dari kegiatan belajar ditandai dengan adanya perubahan perilaku ke arah positif yang relatif permanen pada diri orang yang belajar. Dalam proses peningkatannya, hasil belajar siswa tentu merupakan dampak dari proses dan rancangan pembelajaran yang diterapkan guru di dalam kelas, salah satunya adalah pemilihan model pembelajaran (Depdiknas, 2006:125).

$$
\text { Salah satu pembelajaran yang }
$$
direkomendasikan penerapannya dalam kurikulum 13 ialah pembelajaran Matematika realistik. Pendekatan Pembelajaran Matematika Realistik (PMR) atau yang biasa dikenal dengan Realistic Mathematic Education (RME) merupakan salah satu alternatif pembelajaran yang tepat karena dengan model pembelajaran ini siswa dituntut untuk mengkontruksi pengetahuan dengan kemampuannya sendiri melalui aktivitas-aktivitas yang dilakukannya dalam kegiatan pembelajaran. Ide utama pembelajaran dengan menggunakan model pembelajaran RME adalah siswa harus diberi kesempatan untuk menemukan kembali (reinvention) konsep Matematika dengan bimbingan orang dewasa.

Pembelajaran Matematika Realistik menggabungkan pandangan tentang apa itu Matematika dan bagaimana mengajar dan belajar Matematika (Sutarto Hadi, 2005). Pembelajaran Matematika Realistik adalah suatu pendekatan belajar mengajar yang menggunakan realitas sebagai titik awal dalam proses belajar mengajar yang bertujuan untuk mendukung siswa dalam membangun dan menemukan kembali Matematika melalui masalah kontekstual interaktif (Gravemeijer, 2010:45). 
Pembelajaran Matematika Realistik merupakan suatu pendekatan dalam pembelajaran Matematika. Di Belanda kata "realistik" sering disalah artikan sebagai "real-world", yaitu dunia nyata. Banyak pihak yang menganggap bahwa pendidikan Matematika realistik adalah suatu pendekatan pembelajaran Matematika yang harus selalu menggunakan masalah sehari-hari. Penggunaan kata "realistik" sebenarnya berasal dari bahasa belanda "zich realiseten" yang berarti "untuk dibayangkan" atau "to imagine" (Treffers, 1987) (Van den Heuvel-Panhuien, 1998) (Wijaya, 2011:20).

Prinsip menemukan kembali berarti siswa diberi kesempatan menemukan sendiri konsep Matematika dengan menyelesaikan berbagai soal kontekstual yang diberikan pada awal pembelajaran. Berdasarkan soal siswa membangun model dari (model of) situasi soal kemudian menyusun model Matematika untuk (model for) menyelesaikan hingga mendapatkan pengetahuan formal Matematika (Gravemeijer, 2010). Selain itu dalam pandangan ini, Matematika dipandang sebagai suatu kegiatan manusia. Oleh karena itu pembelajaran Matematika harus dikaitkan dengan realita dan Matematika sebagai bagian dari kegiatan manusia.

Pendekatan Pembelajaran Matematika Realistik memfasilitasi siswa untuk membangun pengetahuannya sendiri sehingga siswa lebih memahami dan mampu menemukan solusi permasalahan secara mandiri (Simanjuntak, 2019:4). Pembelajaran Matematika Realistik bukan hanya suatu metode pembelajaran Matematika, tapi juga suatu usaha melakukan transformasi sosial dimana karakteristik dari pendekatan tersebut adalah agar siswa lebih aktif berpikir, konteks dan bahan ajar terkait langsung dengan lingkungan sekolah dan siswa, serta peran guru lebih aktif dalam merancang bahan ajar dan kegiatan kelas (Sembiring, 2007).

Dalam pembelajaran Matematika realistik, masalah dalam pembelajaran merupakan titik utama proses pembelajaran. Di sini mereka didefinisikan sebagai masalah yang situasi masalahnya secara eksperiensial nyata bagi siswa. Di bawah definisi ini, masalah Matematika murni bisa menjadi masalah konteks juga. Asalkan Matematika yang terlibat menawarkan sebuah konteks, artinya, secara pengalaman nyata bagi siswa (Cobb, 1994). Hal ini didukung oleh pernyataan Gravemeijer And Doorman (1999:111) yang menyatakan bahwa Pembelajaran Matematika Realistik adalah pembelajaran yang melibatkan pada penerapan di dunia nyata. Pengalaman siswa dalam kehidupannya menjadi acuan dalam proses dan permasalahan yang diangkat di kelas. Hal ini membuat siswa lebih berpartisipasi aktif selama proses pembelajaran. Selanjutnya siswa, lebih mudah menghubungkan permasalahan dengan pengalaman mereka sehingga membuat siswa mampu memberikan penjelasan dan memungkinkan solusi yang mungkin dipahami oleh siswa lain. Pembelajaran IRME di kelas dimulai dengan masalah kontekstual yang akrab dengan siswa atau dengan kata lain berada dalam pengalaman dan pengetahuan siswa. Siswa kemudian difasilitasi untuk memecahkan masalah kontekstual yang disajikan. Pemecahan masalah kontekstual 
diketahui memiliki pengaruh positif terhadap kemampuan pemahaman Matematika siswa (Bonotto, 2008: 185-192) (Zakaria \& Syamaun, 2017:38)

Pembelajaran Matematika Realistik terdiri dari enam prinsip; aktivitas, realistis, hierarki, saling terkait, interaksi dan penemuan terpandu (Yenni \& Heck, 2003). Instruksi Pembelajaran Matematika Realistik memberi siswa kesempatan untuk mengembangkan pemahaman mereka sendiri tentang konsep Matematika melalui manipulasi objek dan peralatan. Siswa akan mampu mengembangkan desain struktural kognitif yang akan membantu mereka untuk mengatur pemikiran mereka untuk menafsirkan pengalaman baru melalui eksplorasi aktif (Piaget, 1985). Pembelajaran Matematika Realistik menekankan bahwa prose belajar mengajar harus dikaitkan dengan kehidupan dan pengalaman siswa seharihari. (Van Den Heuvel-Panhuizen, 2003). Proses pembelajaran mengacu pada pertanyaan yang dapat dibayangkan yang diajukan kepada siswa diikuti oleh siswa memecahkan masalah Matematika. Aktivitas siswa dilakukan melalui banyak interaksi dan hal ini akan membangun minat belajar Matematika pada siswa (Wijdeveld, 1980:23-26) (Treffers, 1987) (Ahmad, Slettenhaar \& Plomp, 2002: 1-4).

Agustina (2016:5) dalam hasil penelitiannya mengungkapkan bahwa Pembelajaran Matematika Realistik dalam penelitian tindakan kelas yang dilakukan memberikan hasil yang positif terhadap kemampuan pemahaman konsep dan pemecahan masalah Matematika siswa. Sulastri, Marwan \& Duskri (2017: 67) dalam hasil penelitiannya juga menyimpulkan bahwa Matematika realistik dalam penerapannya efektif jika ditinjau dari kemampuan representasi matematis yaitu menyajikan data atau informasi dari suatu masalah ke representasi tabel, menyelesaikan masalah yang melibatkan ekspresi matematis, serta menuliskan langkah-langkah penyelesaian masalah Matematika dengan katakata. Lebih lanjut Ahmad \& Asmaidah (2017:382) dalam penelitiannya turut mendukung pernyataan bahwa pengembangan perangkat pembelajaran Matematika menggunakan metode Matematika realistik terhitung efektif ditinjau dari kemampuan pemecahan masalah Matematika siswa.

Uzel dan Unyangor (2006:1957) Dari penelitian tersebut terbukti bahwa siswa memiliki sikap positif terhadap Matematika setelah digunakan pendidikan Matematika realistik. Hasil penelitiannya juga menunjukkan bahwa siswa pada kelompok eksperimen menyadari kegunaan Matematika dalam kehidupan sehari-hari setelah pembelajaran. Zakaria \& Syamaun (2017:38) dalam temuan penelitian ini menunjukkan bahwa penggunaan pendekatan pendidikan Matematika realistik dapat meningkatkan prestasi belajar Matematika siswa. Laurens et, al., (2018:576-577) dalam penelitiannya menyatakan bahwa guru Matematika perlu menerapkan RME di kelas untuk membuat konsep Matematika abstrak lebih mudah dipahami. RME juga membantu para guru untuk menyederhanakan dan merealisasikan konsep Matematika.

Makonye (2014: 660-661) RME membantu peserta didik untuk melihat hubungan erat antara pengetahuan konseptual Matematika dan pengetahuan prosedural Matematika. RME dengan 
demikian membantu mengurangi mathophobia dan dengan demikian mempromosikan disposisi produktif dalam Matematika yang merupakan untaian terpenting untuk dipromosikan pembelajaran Matematika yang bermakna. Prestasi dan peningkatan kemampuan penalaran matematis siswa yang diajar dengan pendekatan PMRI lebih baik daripada kemampuan penalaran matematis siswa yang diajar dengan pembelajaran konvensional.

Sementara itu hasil penelitian Asikin \& Junaidi (2013:212) menyatakan RME dapat menumbuhkan kemampuan komunikasi siswa SMP. Karakteristik RME dan komunikasi matematik yang terbangun dalam pembelajaran dalam setting RME.

Tujuan penelitian ini adalah untuk mengetahui penerapan Pembelajaran Matematika Realistik (PMR), untuk materi operasi bilangan pecahan pada siswa kelas VII SMP PGRI 3 Paga tahun pelajaran 2016/2017, untuk mengetahui penerapan Pembelajaran Matematika Realistik dapat meningkatkan hasil belajar untuk materi operasi bilangan pecahan pada siswa kelas VII SMP PGRI 3 Paga tahun pelajaran 2016/2017.

\section{METODE}

Jenis Penelitian yang digunakan adalah penelitian tindakan kelas. Menurut Wardani (2011:1.4), penelitian tindakan adalah penelitian yang dilakukan di dalam kelasnya melalui refleksi diri, dengan tujuan untuk memperbaiki kinerjanya sebagai guru, sehungga prestasi belajar siswa menjadi meningkat.
Pendekatan penelitian yang digunakan dalam penelitian ini adalah pendekatan kualitatif (qualitative research). Bogdan dan Taylor (Moleong, 2007: 4) mendefinisikan metodologi kualitatif sebagai prosedur penelitian yang menghasilkan data deskriptif berupa kata-kata tertulis atau lisan dari orang-orang dan perilaku yang dapat diamati. Fenomena yang dimaksud adalah fenomena penerapan pendekatan Pembelajaran Matematika Realistik (PMR) dalam meningkatkan hasil belajar materi operasi bilangan pecahan pada siswa kelas VII SMP PGRI 3 Paga Tahun Pelajaran 2016/2017.

Prosedur Penelitian Tindakan Kelas secara umum melalui tahapan sebagai berikut: 1) perencanaan (planning) adalah merencanakan program tindakan yang dilakukan untuk meningkatkan hasil belajar Matematika, 2) tindakan (acting) adalah pembelajaran yang dilakukan peneliti sebagai upaya meningkatkan hasil belajar Matematika, 3) pengamatan (observing) adalah pengamatan terhadap siswa selama pembelajarn berlangsung, 4) refleksi (reflection) adalah kegiatan mengkaji dan mempertimbangkan hasil yang diperoleh dari pengamatan sehingga dapat dilakukan revisi terhadap proses belajar-mengajar selanjutnya.

Teknik pengumpulan data dalam penelitian ini menggunakan empat alat pengumpulan data, yaitu wawancara, observasi, tes dan dokumentasi.

1. Wawancara yaitu instrumen untuk mengumpulkan data dalam bentuk sejumlah pertanyaan yang diajukan secara lisan oleh pewawancara kepada responden, dan 
pertanyaan tersebut dijawab secara lisan (Uno, 2011:74).

2. Observasi: penulis menggunakan teknik observasi ini untuk mengamati keadaan siswa sebelum, sedang, dan sesudah pembelajaran melalui penerapan pendekatan Pembelajaran Matematika Realistik (PMR) berlangsung.

3. Tes: alat pengumpulan data ini dipakai untuk mendapatkan data tentang peningkatan hasil belajar Matematika materi operasi bilangan pecahan melalui penerapan pendekatan Pembelajaran Matematika Realistik (PMR) dengan Standar Ketuntasan Minimal (KKM) sebesar 65.

4. Dokumentasi: metode ini digunakan untuk mendapatkan data tentang nama peserta didik Kelas VII SMP PGRI 3 Paga dan gambar/foto pada saat kegiatan pembelajaran Matematika materi operasi bilangan pecahan melalui penerapan pendekatan Pembelajaran Matematika Realistik (PMR) berlangsung.

\section{Populasi dan Sampel}

Penelitian ini dilaksanakan di SMP PGRI 3 Paga, Desa Paga, Kecamatan Paga, Kabupaten Sikka. Penelitian ini dilakukan pada siswa kelas VII SMP PGRI 3 Paga tahun pelajaran 2016/2017 yang berjumlah 24 orang dan sebagai pengamat adalah guru mata pelajaran Matematika kelas VII. Adapun permasalahan yang diteliti berkaitan dengan masalah belajar siswa berupa peningkatan hasil belajar matematika materi operasi bilangan pecahan melalui penerapan pendekatan Pembelajaran Matematika Realistik.

\section{Teknik Analisis Data}

Analisis data penelitian tindakan kelas berupa deskriptif-kualitatif, yaitu suatu metode penelitian yang bersifat menggambarkan kenyataan atau fakta sesuai dengan data yang diperoleh dengan tujuan untuk mengetahui prestasi belajar yang dicapai peserta didik

1. Reduksi Data

Reduksi data merupakan kegiatan menyeleksi data sesuai dengan fokus masalah. Pada tahap ini, peneliti mengumpulkan semua instrumen yang digunakan dalam pengumpulan data kemudian dikelompokkan berdasarkan fokus masalah atau hipotesis.

2. Penyajian Data

Penyajian data merupakan kegiatan mendeskripsikan data sehingga semua data yang diorganisasikan menjadi bermakna. Mendeskripsikan data di sini bisa berupa naratif, tabel, atau grafik. Untuk mengetahui prestasi belajar Matematika materi operasi bilangan pecahan kelas VII SMP PGRI 3 Paga melalui penerapan pendekatan Pembelajaran Matematika Realistik (PMR), maka analisis data penelitian ini dilakukan dengan metode deskriptif kuantitatif, yakni data-data yang ditemukan dalam penelitian disajikan menggunakan statistik deskriptif berupa persentase. 
Tabel 1. Interval Dan Kategori Hasil Belajar

\begin{tabular}{|c|c|}
\hline Interval & Kategori Aktivitas Peserta Didik \\
\hline $85-100$ & Baik Sekali \\
$75-84$ & Baik \\
$65-74$ & Cukup \\
$55-64$ & Kurang \\
$00-54$ & Kurang Sekali \\
\hline
\end{tabular}

Tabel 2. Interval Data Kategori Aktivitas Peserta Didik

\begin{tabular}{|c|c|}
\hline Interval & Kategori aktivitas peserta didik \\
\hline $90-100$ & Sangat baik \\
$70-89$ & Baik \\
$50-69$ & Cukup \\
$30-49$ & Kurang \\
$10-29$ & Sangat kurang \\
\hline
\end{tabular}

3. Penarikan Kesimpulan

Tahap ini sangat penting dilakukan, sebab tanpa adanya kesimpulan maka data yang dianalisis dan disajikan tidak akan berarti apa-apa. Penarikan kesimpulan dilakukan untuk menjawab rumusan masalah dan membuktikan hipotesis.

4. Indikator Kerja

Indikator keberhasilan penelitian adalah apabila penerapan pendekatan Pembelajaran Matematika Realistik (PMR) pada pembelajaran Matemetika materi operasi bilangan pecahan pada peserta didik kelas VII SMP PGRI 3 Paga mencapai angka 65 secara individual dan prestasi belajar peserta didik mencapai nilai 65 sama dengan atau lebih $80 \%$ dari jumlah peserta didik. Apabila kedua hal tersebut sudah dicapai, maka siklus berhenti dan dapat dilakukan analisis data hasil penelitian.

\section{HASIL DAN PEMBAHASAN}

Berdasarkan kajian awal, maka perlu suatu pendekatan pembelajaran yang mampu meningkatkan situasi kelas yang kondusif, peserta didik terlibat aktif dalam belajar, terjadinya komunikasi dua arah, serta siswa meningkat motivasinya untuk belajar. Pembelajaran yang dimaksud adalah pendekatan Pembelajaran Matematika Realistik (PMR) yang dilaksanakan dalam dua siklus.

Penerapan pendekatan Pembelajaran Matematika Realistik (PMR) dalam pembelajaran Matematika materi operasi bilangan pecahan di Kelas VII SMP PGRI 3 Paga dilakukan proses pembelajaran yaitu pada tahap awal:

1. Mengingat kembali tentang konsep bilangan pecahan dan operasi,

2. Guru menyampaikan kompetensi yang akan dicapai dalam aplikasi di kehidupan seharihari,

3. Guru menjelaskan prosedur tentang Pembelajaran Matematika Realistik,

4. Siswa di bagi menjadi 5 kelompok,

5. Guru memberikan instruksi kepada siswa tentang materi pecahan yang akan dipelajari,

6. Guru mulai merangsang siswa dengan memberikan pertanyaan yang berhubungan dengan penggunaan pecahan dalam kehidupan sehari- hari.

Misalnya: Guru menyediakan roti dan di bagikan kepada setiap 2 orang siswa mendapat 1 buah roti. Kemudian roti itu di bagi sama besar kepada teman sebangkunya. Selanjutnya guru membagi lagi roti yang kedua kepada siswa yang masing-masing 1 
buah roti dibagi untuk 4 siswa sama besar.

Setelah siswa masing-masing mendapatkan roti tersebut yaitu roti pertama $1 / 2$ dan roti kedua $1 / 4$, guru mengajukan pertanyaan kepada siswa yaitu: Berapa hasil yang diperoleh apabila 1 buah roti dibagikan kepada 2 siswa dan berapa 1 buah roti dibagikan kepada 4 siswa? Dan Berapa jumlah roti yang diperoleh setiap siswa?

7. Guru menjelaskan singkat tentang kasus tersebut di atas. Kemudian dilanjutkan pada kegiatan inti yaitu: a) guru memberikan lembar kerja siswa kepada masing - masing kelompok yang berisi tentang penggunaan pecahan dalam kehidupan sehari - hari, b) siswa diminta untuk menemukan dan mengembangkan sendiri model-model simbolik secara informal terhadap persoalan yang telah diberikan, c) setelah selesai siswa diminta untuk saling membandingkan jawaban, memahami jawaban temannya, menyatakan ketidaksetujuan, mencari alternatif lain.

Dan pada bagian penutup yaitu: a) dengan bantuan guru siswa diminta untuk menyimpulkan hasil diskusi dari materi yang telah dipelajari, b) siswa mengerjakan latihan tes akhir dengan waktu yang telah ditentukan, c) guru bersama siswa melakukan refleksi, d) guru memberikan tugas dirumah, yaitu mengerjakan soal atau membuat masalah cerita serta jawabannya.

Penerapan pendekatan Pembelajaran

Matematika Realistik membawa pengaruh yang positif terhadap peningkatan hasil belajar
Matematika materi operasi bilangan pecahan, perubahan sikap dan perilaku siswa dalam belajar. Siswa lebih aktif dalam kegiatan pembelajaran. Dengan demikian hasil belajar pun meningkat yang dapat dilihat dari perubahan nilai rata-rata pada table 3 berikut:

Tabel 3. Peningkatan Hasil Belajar

\begin{tabular}{|c|c|c|c|}
\hline $\begin{array}{c}\text { Kondisi Awal } \\
\text { (Pra Siklus) }\end{array}$ & Siklus 1 & Siklus 2 & $\begin{array}{c}\text { Peningkatan } \\
\text { Rata-Rata }\end{array}$ \\
\hline 55,83 & 65,55 & 75,28 & $19,45$. \\
\hline
\end{tabular}

Peningkatan hasil belajar Matematika materi operasi bilangan pecahan melalui penerapan pendekatan Pembelajaran Matematika Realistik pada siswa VII SMP PGRI 3 juga diikuti dengan perubahan perilaku yang dialami oleh siswa setelah mengikuti pembelajaran Matematika ke arah yang lebih baik. Hal tersebut terbukti pada perilaku siswa yang memperhatikan penuh kosentrasi pada siklus I sebanyak 14 orang dari 24 siswa atau 58,33\%, sedangkan pada siklus II terjadi peningkatan perilaku siswa yang memperhatikan penuh kosentrasi sebanyak 21 orang dari 24 siswa atau 87,5\%.

Penelitian ini memberikan hasil bahwa pendekatan Matematika realistik memberikan hasil yang efektif terhadap hasil belajar Matematika siswa. Hal ini sejalan dengan penelitian yang dihasilkan oleh Sumianto (2018: 54) yang menyatakan bahwa RME dalam pembelajaran Matematika efektif dalam meningkatkan hasil belajar. Pembelajaran Matematika paling baik dilakukan dengan memberikan siswa secara aktif memecahkan masalah kontekstual. Siswa menghadapi masalah Matematika dalam 
kehidupan sehari-hari. Guru dapat menggunakan kegiatan sehari-hari informal yang diketahui siswa untuk membantu mereka mengidentifikasi situasi Matematika.

Lebih lanjut hasil penelitian dalam penelitian ini juga didukung oleh hasil penelitian Herlina \& Taufina (2020:287) yang menyatakan bahwa langkah-langkah pembelajaran pada PMR membantu siswa untuk lebih siap dalam proses pembelajaran di kelas. Sementara itu, hasil penelitian ini juga mengungkapkan bahwa siswa dalam proses pembelajarannya terlihat aktif dan antusias ketika belajar sehingga berpengaruh positif terhadap hasil belajar yang diperoleh. Hasil ini sejalan dengan penelitian yang dilakukan oleh Hidayah, Relmasira \& Hardini (2019:353) yang dalam hasil penelitiannya menunjukan bahwa Pembelajaran Matematika Realistik ditinjau efektif jika dilihat dari keaktifan dan hasil belajar siswa

RME dalam proses pembelajarannya mendukung keaktifan siswa dan mendukung proses pemecahan masalah siswa dalam pembelajaran Matematika. Hal ini tentu berpengaruh terhadap hasil belajar Matematika siswa. Temuan ini didukung oleh pendapat Suci, Firman \& Neviyarni (2019: 2047) yang dalam hasil penelitiannya menemukan bahwa Pembelajaran Matematika Realistik efektif dalam meningkatkan keterampilan berpikir kritis siswa. Siswa menjadi terlatih secara sistematis dan terorganisir. Disamping itu, siswa juga terlihat semakin aktif, termotivasi dalam belajar jika diajarkan dengan pendekatan Matematika realistik. Saran yang dapat diberikan kepada guru hendaknya dapat menerapkan strategi, model, dan pendekatan yang lebih bervariasi dalam pembelajaran, agar siswa lebih antusias dalam belajar.

Dalam penelitian ini juga terlihat bahwa kemampuan pemecahan masalah matematis dan kemandirian belajar siswa meningkat setelah pembelajaran menggunakan pendekatan Matematika realistik. Terlihat bahwa kualitas pembelajaran harus memenuhi kriteria efektif. Hal ini didukung oleh hasil penelitian yang dilakukan Hasibuan, Saragih \& Amry (2019: 250) yang dalam penelitiannya menggunakan perangkat pembelajaran Matematika dengan pendekatan Pembelajaran Matematika Realistik terhitung efektif, praktis dan juga valid.

Selain itu, hasil penelitian ini juga mengungkapkan bahwa penerapan Pembelajaran Matematika Realistik menuntut guru perlu lebih kreatif dan inovatif dalam merancang pembelajaran dengan pendekatan ini. Pengembangan media pembelajaran sebagai alat bantu dalam mengkonkritkan objek Matematika juga dianjurkan untuk memudahkan guru dalam berkomunikasi dan mengajarkan konsep tersebut terhadap siswa (Lauren, et al., 2018:576-577).

Hasil penelitian ini diharapkan dapat memberikan gambaran kepada para guru agar dapat menggunakan Pendidikan Matematika Realistis (PMR) ke dalam kurikulum mereka, sehingga guru peserta pelatihan dapat menggunakan pendekatan baru ketika mereka menjadi guru di sekolah (Zakaria \& Syamaun, 2017:38). 


\section{SIMPULAN}

Dari hasil penelitian yang telah dilaksanakan dapat disimpulkan bahwa: Penerapan pendekatan Pembelajaran Matematika Realistik (PMR) dapat meningkatkan hasil belajar Matematika materi operasi bilangan pecahan pada siswa kelas VII SMP PGRI 3. Peningkatan pembelajaran Matematika materi operasi bilangan pecahan pada siswa kelas VII SMP PGRI 3 melalui penerapan pendekatan Pembelajaran Matematika Realistik dapat dilihat dari hasil belajar siswa pada rekapitulasi perbandingan nilai rata-rata pada tabel data yang telah disajikan, yaitu prasiklus sebesar 55,83. Setelah dilakukan pembelajaran Matematika materi operasi bilangan pecahan melalui penerapan pendekatan Pembelajaran Matematika Realistik siklus I meningkat menjadi 65,55 (kategori cukup), pada siklus II meningkat menjadi 75,28 (kategori baik).

Secara keseluruhan peningkatan pembelajaran Matematika materi operasi bilangan pecahan pada siswa kelas VII SMP PGRI 3 melalui penerapan pendekatan Pembelajaran Matematika Realistik dari prasiklus ke siklus II sebesar 19,45. Peningkatan hasil belajar Matematika materi operasi bilangan pecahan melalui penerapan pendekatan Pembelajaran Matematika Realistik (PMR) juga diikuti oleh perubahan perilaku siswa kelas VII SMP PGRI 3 ke arah yang lebih positif setelah dilaksanakan pembelajaran Matematika materi operasi bilangan pecahan melalui penerapan pendekatan Pembelajaran Matematika Realistik (PMR)

\section{DAFTAR PUSTAKA}

Ahmad, M. \& Asmaidah, S. 2017. Pengembangan perangkat pembelajaran matematika realistik untuk membelajarkan kemampuan pemecahan masalah matematika siswa SMP. Mosharafa: Jurnal Pendidikan Matematika. 6(3), 373-384.

Ahmad Fauzan, Slettenhaar, D. \& Plomp, T. (2002). Traditional mathematics education Vs realistic mathematics education: Hoping for changes. In P. Valero \& O. Skovsmose, Proceedings of the 3rd International Mathematics Education and Society Conference. Copenhagen Denmark, Centre for Researh in Learning Mathematics

Agustina, Lisna. 2016. Upaya Meningkatkan Kemampuan Pemahaman Konsep dan Pemecahan Masalah Matematika Siswa Smp Negeri 4 Sipirok Kelas VII Melalui Pendekatan Matematika Realistik (PMR). Eksakta. 1(1), 1-7

Arends. 2007. Model-model Pembeljarana Invatif berorientasi konstuktivitas. Jakarta: Prestasi Pustaka Publisher

Arikunto, Suharsimi. 2010. Prosedur Penelitian Suatu Pendekatan Praktik. Jakarta: Rineka Cipta.

Asikin, M. \& Junaedi M. Kemampuan Komunikasi Matematika Siswa Smp Dalam Setting Pembelajaran Rme (Realistic Mathematics Education). Unnes Journal of Mathematics Education Research 2 (1). 203-213

Bonotto, C. (2008). Realistic mathematical modeling and problem posing. In W. Blum, P. Galbraith, M. Niss. H. W. Henn (Eds.) Modelling and Applications in Mathematics Education. New York: Spinger.

Cobb, P. 1994. Theories of Mathematical Learning and Construction: A Personal View. Paper symposium on Trends and Perspectives in Mathematics Education, Klagenfurt: Germany 
Depdiknas. 2006. Bunga Rampai Keberhasilan Guru Dalam Pembelajaran (SMA, SMK dan SLB). Jakarta: Depdiknas

GRAVEMEIJER, K. \& DOORMAN, M. 1999. Educational Studies in Mathematics. Netherlands: Kluwer Academic Publishers.

Gravemeijer, K. (2010). Realistic mathematics education theory as a guideline for problemcentered, interactive mathematics education. In R. Sembiring, K Hoogland \& M. Dolk (Eds.), A decade of PMRI in Indonesia, (pp.41-50). Bandung, Utrecht: APS International.

Hasibuan, A. M., Saragih \& Amry, Z. 2019. Development of Learning Materials Based on Realistic Mathematics Education to Improve Problem Solving Ability and Student Learning Independence. International Electronic Journal of Mathematics Education. 14(1), 243-252

Herlina, F. \& Taufina. 2020. Peningkatan Hasil Belajar Matematika Melalui Pembelajaran Matematika Realistik di Sekolah Dasar. Jurnal Basicedu. 4(4) 821-828.

Hidayah, N., Relmasira, S. C. \& Hardini, A. T. A. 2019. Meningkatkan Keaktifan Dan Hasil Belajar Matematika Melalui Model Pembelajaran Matematika Realistik Untuk Siswa Kelas IV SD. Jurnal Basicedu. 3(2), 345-354

Laurens, et. al. 2018. How Does Realistic Mathematics Education (RME) Improve Students' Mathematics Cognitive Achievement? Eurasia Journal Of Mathematics, Science And Technology Education. 14(2):569-578

Makonye, J. P. 2014. Teaching Functions Using a Realistic Mathematics Education Approach: A Theoretical Perspective. Int J Edu Sci, 7(3): 653-662
Moleong, Lexy J. 2012. Metode Penelitian Kualitatif Edisi Revisi. Bandung: PT Remaja Rosdakarya

Nana Sudjana 2010. Dasar-dasar Proses Belajar, Bandung: Sinar Baru Bandung

Piaget, J. (1985). The equilibrium of cognitive structures: The central problem of intellectual development. Chicago: University of Chicago Press

Ratumanan. 2000. Pengantar Penelitian Ilmiah Dasar Metode dan Teknik. Bandung: Tarsito

Saleh, et. al. 2018. Improving The Reasoning Ability Of Elementary School Student Through The Indonesian Realistic Mathematics Education. Journal on Mathematics Education. 9(1), pp. 41-54 41

Simanjuntak, S. D. 2019. Pengembangan Pembelajaran Matematika Realistik dengan Menggunakan Konteks Budaya Batak Toba. Surabaya: CV. Jakad Publishing.

Soedjadi, R. (1999) Kiat Pendidikan Matematika di Indonesia. Jakarta: Direktorat Pendidikan Tinggi Departemen Pendidikan Nasional.

Sumianto, S. 2018. Penerapan Pendekatan Matematika Realistik (PMR) Untuk Meningkatkan Hasil Belajar Matematika Siswa Kelas V Al-Azim Sdit Raudhatur Rahmah Pekanbaru. Jurnal Basicedu. 2(1). 49-56

Suci, D. W. Firman, F. \& Neviyarni, N. 2019. Peningkatan Keterampilan Berpikir Kritis Siswa Melalui Pendekatan Realistik Di Sekolah Dasar. Jurnal Basicedu. 3(4), $2042-$ 2049

Sudjana, Nana. 2010. Penilaian Hasil Proses Belajar Mengajar. (Cet. XV). Bandung: PT. Remaja Rosdakarya

Sulastri, S., Marwan, M. \& Duskri, M. 2017. Kemampuan Representasi Matematis Siswa Smp Melalui Pendekatan Pendidikan 
Matematika Realistik. Beta: jurnal tadris matematika. 10(1), 51-69

Sembiring, R., Hoogland, K \& Dolk, M. 2010. A decade of PMRI in Indonesia, Bandung, Utrecht: APS International.

Susanto, Ahmad. 2013. Teori Belajar dan Pembelajaran di Sekolah Dasar. Jakarta: Kencana Prenada Media Group.

Sutarto Hadi (2005). Pendidikan matematika realistik dan implementasinya. Banjarmasin: Tulip

Taufiq, Agus dkk. 2011. Pendidikan Anak di SD. Jakarta : UT

Treffers, A. (1987). Three dimension. A model of goal and theory description in mathematics education, Dordrecht: Riedel

Uno, B Hamzah. 2011. Model Pembelajaran. Jakarta: Bumi Aksara

Uzel, D. \& Uyangor, S.M. 2006. Attitudes of 7th Class Students Toward Mathematics in Realistic Mathematics Education. International Mathematical Forum 1(39) 1951-1959

van den Heuvel-Panhuizen, Marja. 2003. The didactical use of models in Realistic Mathematics Education: An example from a longitudinal trajectory on percentage. Educational Studies in Mathematics 54: 9-35

Wardani, I G A K dkk. 2011. Penelitian Tindakan Kelas. Jakarta: UT

Wijaya, Aryadi. 2011. Pendidikan Matematika Realistik Suatu alternatif Pendekatan Pembelajaran Matematika. Yogyakarta: Graha Ilmu

Wijdeveld, E. (1980). Zich realiseren, in IOWO, de achterkant van de Mobius, IOWO. Utrecht, The Netherland

Yenni Widjaya, \& Heck, A. 2003. How a Realistic Mathematics Education approach and microcomputer-based laboratory worked in lessons on graphing at an Indonesian Junior High School. Journal of Science and Mathematics Education in Shoutheast Asia, 26, 1-51.

Zakaria, E. \& Syamaun M. The Effect of Realistic Mathematics Education Approach on Students' Achievement And Attitudes Towards Mathematics. Mathematics Education Trends and Researc. 2017(1) 3240 